\title{
Distribution, ecology and conservation status of two endemic amphipods, Echinogammarus acarinatus and Fontogammarus dalmatinus, from the Dinaric karst rivers, Balkan Peninsula
}

\author{
Krešimir Žganec ${ }^{1 *}$, Petra Lunko ${ }^{2}$, Andrej Stroj ${ }^{3}$, Tomasz Mamos ${ }^{4}$ and Michal Grabowski ${ }^{4}$ \\ 1 Department of Teacher Education Studies in Gospić, University of Zadar, dr. Ante Starčevića 12, 53000 Gospić, Croatia \\ 2 Croatian Agency for Environment and Nature, Radnička cesta 80/7, 10000 Zagreb, Croatia \\ 3 Croatian Geological Survey, Sachsova 2, 10000 Zagreb, Croatia \\ 4 Department of Invertebrate Zoology and Hydrobiology, Laboratory of Biogeography and Invertebrate Ecology, University of \\ Lodz, St. Banacha 12/16, 90-237 Lodz, Poland
}

Received 21 July 2015; Accepted 07 December 2015

\begin{abstract}
The Balkan Peninsula is recognized to be one of the most important biodiversity hotspots worldwide. However, biogeographic patterns of its freshwater fauna are poorly understood due to the lack of basic data on distribution and ecology, particularly for endemic taxa. We studied the distribution, habitats and conservation status of two endemics, Echinogammarus acarinatus and Fontogammarus dalmatinus, in the Dinaric karst rivers. Altogether, 711 sites were sampled from 2000 to 2014 and supplemented by literature data. Although previously known only from rivers of the Adriatic Sea (AS) basin, both species were also found in the Black Sea (BS) basin. E. acarinatus has a mosaic distribution extending from the Una River to the delta of the Neretva River, particularly in the rivers Vrbas and Bosna (BS). Its presence in the AS basin rivers, Krka and Neretva, could result from river capture events by which former tributaries of the Una and Bosna (BS) were directed to the AS basin. Two subspecies of $F$. dalmatinus are distributed in the Una, Zrmanja and Krka Rivers. F. dalmatinus dalmatinus occurs in upper and middle parts of the Zrmanja (AS), and in the upper part of the Una (BS), while $F$. dalmatinus krkensis was found exclusively in springs and upper parts of the Krka (AS). Distribution of both subspecies in the Zrmanja and Krka indicates former connection between these rivers. The ecology and conservation status of all the studied taxa are presented and discussed. This study illustrates the importance of including ecological and historical interpretations of species' distributions for managing conservational issues in the case of freshwater endemics with narrow ranges.
\end{abstract}

Key words: Freshwater / biogeography / endemic gammarids / microdistribution

\section{Introduction}

Due to its complex geological history and unique combination of geological and climatic factors, the widely defined Mediterranean Region, including the Balkan Peninsula, is recognized as one of the most important hot-spots of biodiversity and endemism globally (Griffiths et al., 2004; Woodward, 2009; Blondel et al., 2010). Particularly, freshwater habitats are characterized by high levels of endemism resulting from isolation and allopatric speciation combined with specific habitat requirements and limited dispersal abilities of many freshwater organisms (Strayer, 2001, 2006). The Mediterranean Region houses at least $35 \%$ of the Palearctic freshwater species,

\footnotetext{
*Corresponding author: kzganec@unizd.hr
}

with nearly half being local endemics (Tierno de Figueroa et al., 2013). Species that have restricted geographical distributions are particularly vulnerable to habitat destruction, giving freshwaters a high degree of irreplaceability (Dudgeon et al., 2006). In fact, the extinction rate of freshwater invertebrates is higher than in terrestrial groups, mostly due to the heavy anthropogenic degradation of aquatic ecosystems. Adding to that, no more than $1 \%$ of invertebrates have been assessed with regards to their conservation status by the International Union for Conservation of Nature (IUCN) (Borrell, 2012). This leads to a situation in which the rate of extinctions will exceed the rate of identification and description of biodiversity. What is even worse, the biogeographic patterns of freshwater invertebrate fauna remain poorly known and understood due to the lack of basic data on distribution 
and ecology, particularly of endemic taxa. Without such knowledge, it is difficult to plan reasonable and effective strategies preventing or at least minimizing the loss of biodiversity. It must also be remembered that planning and implementing such strategies is one of the top priorities of many EU and global agendas for conservation of natural resources (European Commission, 2011).

Amphipod crustaceans are known to have restricted distributions and many are narrow-ranged endemics (Väinölä et al., 2008). For example, more than half of freshwater species of the family Gammaridae have restricted distributions with centers of endemism in the Iberian, Apennine and Balkan Peninsulas. The karst rivers of the Balkan Peninsula are well known for their endemic gammarid fauna. There are 17 endemic freshwater morphospecies of the genus Gammarus (Karaman and Pinkster 1977a, 1977b, 1987) and seven species in the genus Echinogammarus in the Balkan Peninsula (Pinkster, 1993), with three endemic Balkan Echinogammarus species, Echinogammarus cari (S. Karaman, 1931), Echinogammarus acarinatus (S. Karaman, 1931), Echinogammarus thoni (Schäferna, 1922), occurring in Croatia (Žganec, 2009). Fontogammarus and Jugogammarus are two endemic Balkan monotypic genera of epigean gammarids with Fontogammarus dalmatinus S. Karaman, 1931 in Croatia (Karaman, 1965; Žganec, 2009; Žganec et al., 2010a) and Jugogammarus kusceri S. Karaman, 1931 in Slovenia (Karaman, 1931). However, based on recent molecular studies that focus on cryptic diversity of Gammaridae in Europe, these numbers are probably largely underestimated (Mamos et al., 2014, 2015; Weiss et al., 2014).

A case study of endemic Croatian E. cari, now endangered due to damming (Žganec et al., 2013), clearly showed deterioration of its population due to the adverse human impact. This provides a strong argument for studies on the distribution and conservation status of the endemic Balkan amphipods. Moreover, distributional patterns of such obligate freshwater organisms with limited dispersal abilities may provide interesting and important evidence of former connections between now isolated river systems - particularly useful in the Balkan Peninsula where dynamic geology has often reshaped local hydrological networks (Fritz, 1972; Vlahović et al., 2012).

Except for the well-studied E. cari (Žganec and Gottstein, 2009; Žganec et al., 2011, 2013) and E. thoni (Žganec et al., 2010b) with relatively well-mapped distribution, very little is known about other gammarids endemic to the Balkans. Only Laurogammarus scutarensis (Schäferna, 1922) from the Skadar Lake basin was recently studied in more detail with respect to its reproductive biology (Grabowski et al., 2014). Most of the remaining species are known only from their type localities or very few other places and have been documented solely on the occasion of species description (Karaman and Pinkster, 1977a, 1977b, 1987; Pinkster, 1993).

The present study aims: (1) to give an overview of all recent and literature data on the distribution, habitats and conservation status of two gammarid species, i.e., E. acarinatus (S. Karaman, 1931) and F. dalmatinus S. Karaman, 1931, with its two subspecies $F$. dalmatinus dalmatinus and $F$. dalmatinus krkensis, endemic to watercourses of the Dinaric karst in Croatia and Bosnia and Herzegovina; (2) to interpret their distribution in the context of local paleogeography and past connections between now isolated drainage basins; (3) to provide basic ecological data for the species and subspecies and finally; (4) to propose and discuss the conservation status for the studied taxa. Finally, we aim to illustrate the importance of thorough faunistic surveys including habitat information and historical interpretation of species' distributions for managing conservational issues in the case of freshwater endemics.

\section{Methods}

The data on the distribution of E. acarinatus and $F$. dalmatinus were gathered from our own field surveys and from the literature (Schäferna 1920, 1922; Karaman, 1931a, 1931b, 1934, 1935; Karaman, 1965, 1970; Pljakić, 1962; Pinkster, 1993; Gottstein et al., 2008). The literature records not overlapping with our sampling sites are shown in Figure 1. Altogether, samples from 711 sites were included in this study (Fig. 1). Sampling was done with various methods (both qualitative and quantitative) using rectangular kick sample nets $\left(25 \times 25 \mathrm{~cm}^{2}\right.$ with 0.5 or $0.2 \mathrm{~mm}$ mesh size), between 2000 and 2014. A great variety of lotic and lentic habitats were sampled, ranging from springs through small and medium streams and large rivers to different types of lakes. The samples were instantly fixed in $75 \%$ ethanol. Temperature, dissolved oxygen, conductivity, salinity and $\mathrm{pH}$ were measured with a WTW probe. All the sampled localities were geocoded with a GPS receiver, while the geographic coordinates for literature data were based on locality description, using 1:25.000 topographic maps and GoogleEarth. Some literature sources (e.g., Pljakić, 1962) did not mention the locality but only streams in which the material was collected. In such cases, sites in the middle part of identified streams were chosen. Gauss-Krüger coordinates were determined for each site and the data were mapped using ArcMap in the ArcGIS 9.2 program package (1999-2006 ESRI Inc.). The samples were sorted in the laboratory to separate gammarids from the substrate. The gammarids were identified according to the keys by Karaman and Pinkster (1977a, 1977b, 1987) and Pinkster (1993).

Density of gammarids in two dominant microhabitats, moss and stony substrate, was assessed by collecting, with a rectangular benthic net $\left(25 \times 25 \mathrm{~cm}^{2}\right.$ and $0.2 \mathrm{~mm}$ mesh size), five replicate samples, one from each of the three following localities (Fig. 2: K1, D1 and Z6). Site K1 was located in the upper course of Krka, approximately $200 \mathrm{~m}$ downstream from its main spring, site D1 at spring of Dobarnica (Zrmanja right tributary) and site Z6 at the upper Zrmanja, approximately $16 \mathrm{~km}$ downstream of 


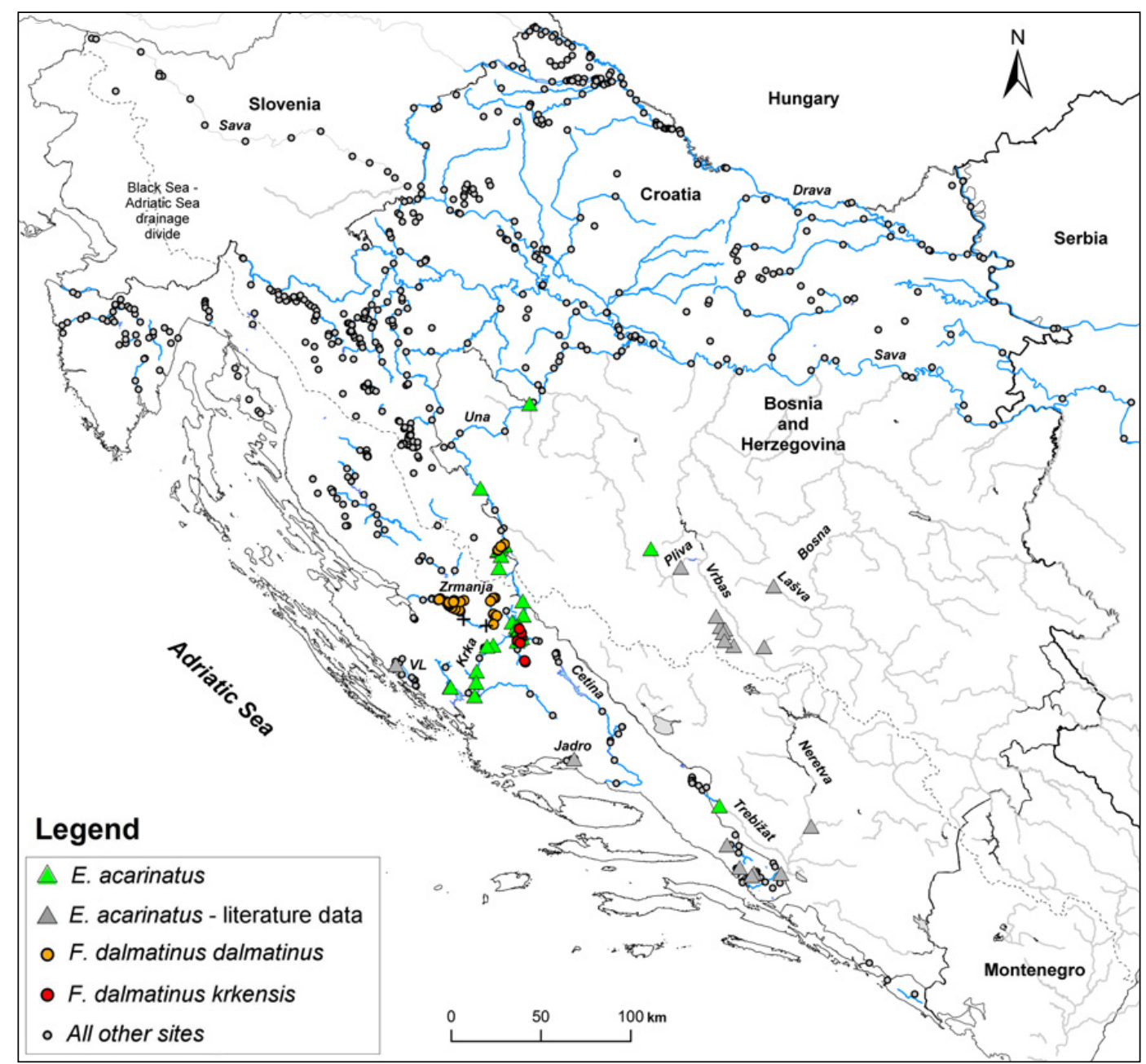

Fig. 1. Distribution of Echinogammarus acarinatus and Fontogammarus dalmatinus with its two subspecies, F.d.dalmatinus and F. d. krkensis in Croatia and Bosnia-Herzegovina (VL-Vransko Lake).

the river main spring. The sampling area for the stony substrate was $0.0625 \mathrm{~m}^{2}\left(25 \times 25 \mathrm{~cm}^{2}\right)$. Moss samples, due to very high gammarid density, were collected from a surface of $0.01 \mathrm{~m}^{2}\left(10 \times 10 \mathrm{~cm}^{2}\right)$ using a rectangular frame placed on moss-covered stones from which mosses were picked by hand into downstream placed nets. Adult and subadult gammarids were identified to species level, while juvenile individuals could not be identified due to lack of diagnostic features. Thus, the density and relative abundance of gammarids was assessed based exclusively on adult and subadult individuals. Density data were log-transformed to achieve normal distribution (Zar, 1996). The differences between densities of each gammarid species and between two types of microhabitats were tested using an unpaired $t$-test, while differences among densities of three gammarid species present at site $\mathrm{K} 1$ were tested using analysis of variance (ANOVA). Relative abundance was calculated as the percentage of species abundance per sample-microhabitat in total number of individuals (adults + subadults identified to species level) of two (sites D1 and Z6) or three species (site K1) present in each sample. The difference in relative abundance of each species between two microhabitats was tested using non-parametric Mann-Whitney (M-W) $U$-test, and the difference between relative abundance of three species at site $\mathrm{K} 1$ was tested using a non-parametric Kruskal-Wallis test. Differences in relative abundances of two subspecies of $F$. dalmatinus between two groups of sites were tested using an $\mathrm{M}-\mathrm{W} U$-test. Physical-chemical parameters were available for 53 sites (of 90 sites in total) in the Krka, Zrmanja and Una Basins. Between-basin differences in five physical-chemical parameters (mostly measured only once in spring months), altitude, distance to the source and mean width (all variables logtransformed) were tested using ANOVA. The level of significance was set at $P=0.05$. The statistical software package Statistica 7.1 (Systat Software Inc., Richmond, CA, USA) was used for all univariate tests. Multivariate analyses were performed in PRIMER 6.1.6 (PRIMER-E Ltd 2006): non-parametric multidimensional scaling (NMDS) for six gammarid taxa abundance (log-transformed) at 90 sites in the Krka, Zrmanja and Una Basins and correlation-based principle component analysis (PCA) for gammarid abundance and the above-mentioned abiotic parameters at subset of 53 sites in the Krka, Zrmanja and Una Basins. 




Fig. 2. Sampling sites in the catchments of the Zrmanja, Krka and upper part of the Una (the part of the middle Zrmanja between black crosses dries up during summer months).

\section{Results}

\section{General distribution}

Distribution of the two endemic gammarids, $E$. acarinatus and $F$. dalmatinus, derived from our own and literature records are shown in Figures 1 and 2 . E. acarinatus has rather wide distribution, from the basins of the Una and Vrbas Rivers in the north to the Neretva River system in the south. In the Adriatic Sea (AS) drainage basin it was found only in the systems of Krka and Neretva, while it was not recorded in the system of Zrmanja (30 sites surveyed), Jadro (four sites surveyed) and Cetina (14 sites surveyed). In the Krka system, gammarids were collected altogether at 37 sites, and E. acarinatus was recorded at 19 of them: almost along the whole course of the Krka, from its main source to the Skradinski Buk travertine waterfall, the most downstream freshwater site below which the Krka estuary begins. Interestingly, although we collected samples at 33 sites in the Neretva river system, namely 16 sites in the Neretva delta, 16 sites at three sinking rivers in the Neretva Basin in
Croatia and one at a site on the left tributary Trebižat, we found E. acarinatus only at one site - the main spring of the Trebižat River in Bosnia and Herzegovina. Further, according to Karaman (1931a, 1931b) it was also found in a tributary of the Vransko Lake and in the Jadro River (Fig. 1). However, since we did not confirm these localities by our sampling, we consider them as doubtful. In the Black Sea (BS) drainage basin, E. acarinatus was recorded in the systems of the Una, Vrbas and Bosna Rivers (Fig. 1). Pljakic (1962) found this species in eight tributaries of the Vrbas and at one site in the Bosna system. In the Una River, E. acarinatus was found along the first $6 \mathrm{~km}$, in the middle course at a site $42 \mathrm{~km}$ downstream of the main spring and in the lower course at a site about $132 \mathrm{~km}$ downstream from the main spring. Also, it was found in four tributaries of the upper course of the Una. Altogether, E. acarinatus was recorded at 28 sites (19 in the Krka and 9 in the Una systems). At most sites it co-occurs with Gammarus balcanicus; at five sites in the Krka (in Croatia) and at four sites in the Una Basin it was found together with $F$. dalmatinus and $G$. balcanicus, while at four sites in the Krka Basin it was the sole species found (Fig. 3(a)). 


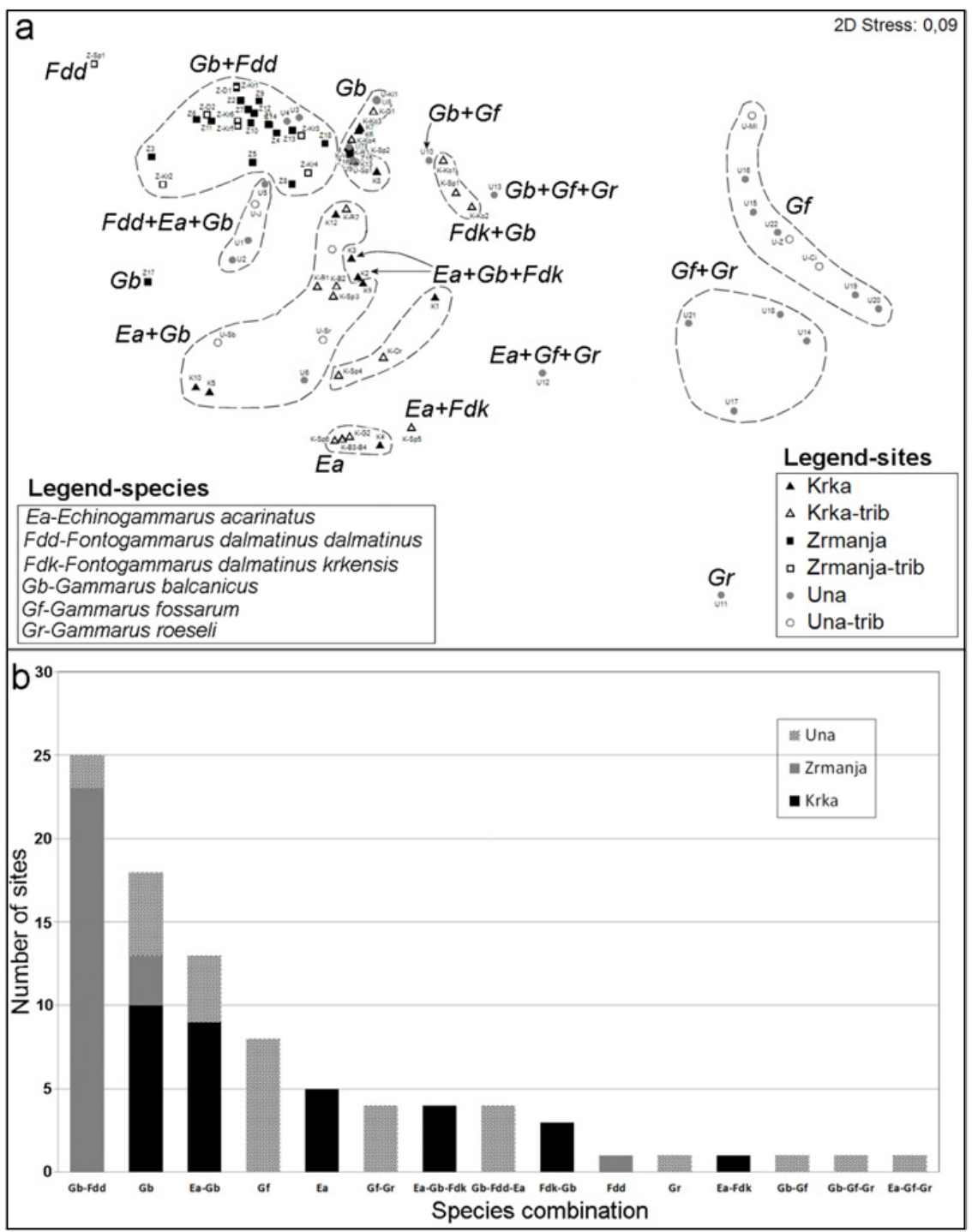

Fig. 3. (a) Non-parametric Multidimensional Scaling (NMDS) of 90 sites based on log-transformed abundances of six gammarid taxa in the Krka, Zrmanja and Una Basins. Sites are shown based on their position along the course of studied rivers or their tributaries (a higher number of sites in labels means that the site is more downstream). Grouping of sites is based on the combination of species present (marked by letters-abbreviation of species names); (b) number of sites with specific combinations of species in the Krka, Zrmanja and Una basins (90 sites in total).

Two subspecies of $F$. dalmatinus were found in three different river basins: $F$. dalmatinus dalmatinus in the Una and Zrmanja drainages and $F$. dalmatinus krkensis in the Krka system (Figs. 1 and 2). The subspecies $F$. dalmatinus dalmatinus was recorded in the upper and lower Zrmanja as well as in the upper part of the Una River. In the Zrmanja system, it was found at 24 of the 30 sampled sites. Since the middle part of Zrmanja, about $14 \mathrm{~km}$ long, completely dries up during summer months, the river has permanent upper and lower courses and an intermittent middle course (Fig. 1). F. dalmatinus dalmatinus was present along the whole course of the upper Zrmanja, from the main spring (Z1) to site Z6 about $16 \mathrm{~km}$ downstream of the main spring (Fig. 2) and it is probably also present about $5 \mathrm{~km}$ downstream of Z6 where the intermittent middle part begins. In the lower Zrmanja, it was continuously distributed up to the site $0.9 \mathrm{~km}$ downstream of the Krupa confluence (about $11 \mathrm{~km}$ from the beginning of the permanent lower Zrmanja) and along the whole courses in its permanent right tributaries Krupa (10 km long) and Dobarnica (1 km). In Una, F. dalmatinus dalmatinus was found to be continuously distributed in the first $6 \mathrm{~km}$ downstream of the main source (to the mouth of Krka, right tributary). Further, it was found only at one site and absent from three other sites located in tributaries of the Una upper course. It co-occurs only with G. balcanicus in the Zrmanja system and with E. acarinatus and $G$. balcanicus in the Una system.

The subspecies $F$. dalmatinus krkensis was recorded at nine of the 37 sampling sites in the Krka Basin: at three sites in the upper course of Krka (K1-K3), in the spring and in the upper course of the Krka left tributary (stream 
Table 1. Physical-chemical parameters at all sites where Fontogammarus dalmatinus krkensis (F.d.k.), F. dalmatinus dalmatinus (F.d.d.) and Echinogammarus acarinatus (E.a.) were recorded. Average values, ranges and number of sites (in parenthesis) are shown.

\begin{tabular}{|c|c|c|c|}
\hline $\begin{array}{l}\text { Species/subspecies } \\
\text { River basin }\end{array}$ & $\begin{array}{l}\text { F.d.k. } \\
\text { KRKA }\end{array}$ & $\begin{array}{c}\text { F.d.d. } \\
\text { ZRMANJA and UNA }\end{array}$ & $\begin{array}{c}E . a . \\
\text { KRKA and UNA }\end{array}$ \\
\hline \multirow[t]{2}{*}{ Water temperature $\left({ }^{\circ} \mathrm{C}\right)$} & $11.5(9)$ & $10.9(21)$ & $12.0(20)$ \\
\hline & $10.1-12.7$ & $8.7-18.3$ & $5.6-25.0$ \\
\hline \multirow[t]{2}{*}{ Dissolved oxygen $\left(\mathrm{mg} \mathrm{O}_{2} \cdot \mathrm{L}^{-1}\right)$} & $10.4(9)$ & $10.8(20)$ & $10.6(19)$ \\
\hline & $9.5-11.7$ & $7.4-12.9$ & $8.7-13.4$ \\
\hline \multirow[t]{2}{*}{ Oxygen saturation $(\%)$} & $97.5(9)$ & $100.3(12)$ & $100.8(19)$ \\
\hline & $90.7-112.3$ & $71.6-125.8$ & $86.2-119.1$ \\
\hline \multirow[t]{2}{*}{ Conductivity $\left(\mu \mathrm{S} . \mathrm{cm}^{-1}\right)$} & $426.3(8)$ & 388.8 (19) & $560.0(18)$ \\
\hline & $365-472$ & $322-584$ & $365-1007$ \\
\hline \multirow[t]{2}{*}{$\mathrm{pH}$} & $7.7(8)$ & $7,9(19)$ & $7.9(18)$ \\
\hline & $7.5-8.0$ & $7.0-8.7$ & $7.4-8.3$ \\
\hline
\end{tabular}

Kosovčica) and at four additional springs of Krka and Kosovčica near the town of Knin (two of those springs in Fig. 2 are very close and appear as one dot). The most downstream locality of this subspecies in the upper course of Krka (K3) was $3 \mathrm{~km}$ from its main spring. F. dalmatinus krkensis co-occurs with E. acarinatus and G. balcanicus at six sites, only with E. acarinatus in one spring and only with $G$. balcanicus at two sites in Kosovčica.

\section{Abundance and distribution in the Krka, Zrmanja and Una Basins}

Results of the NMDS performed on the 90 sites in Krka, Zrmanja and Una with log-transformed abundances of six gammarid taxa are shown in Figure 3(a) (nine sites without gammarids or with brackish water species were excluded from the analysis). There is a clear separation of sites with $G$. balcanicus and different combinations of three endemic taxa (E. acarinatus and two ssp. of $F$. dalmatinus) in the Krka, Zrmanja and upper and middle Una (right groups in Fig. 3(a)), from the sites located along the lower course of the Una and its tributaries where only Gammarus fossarum and Gammarus roeseli were found. Two sites where $G$. balcanicus co-occurs with G. fossarum (U10) and G. fossarum and $G$. roeseli (U13) are more similar to groups on the left side of the graph due to dominance of $G$. balcanicus. One site, where E. acarinatus co-occurred with $G$. fossarum and $G$. roeseli, is between two groups. There are altogether 15 combinations of the recorded species, with most of them (12) in the Krka, Zrmanja and upper and middle Una. Most sites $(47,52 \%)$ have only two species (Fig. 3(b)). Sites with a combination of G. balcanicus and $F$. dalmatinus dalmatinus were most common, present mostly in the Zrmanja system. Of the six gammarid taxa, only $F$. dalmatinus krkensis was never found alone, while $F$. dalmatinus dalmatinus was a sole species only at one site (spring of small right tributary of lower Zrmanja, Z-Sp1 in Fig. 3(a)). Sites in the Zrmanja Basin with two taxa, $G$. balcanicus and $F$. dalmatinus dalmatinus, are grouped close together. These sites are similar to those in the upper Una where E. acarinatus was also found with the former two species. Sites in the Krka system are scattered on the left side of the graph in Figure 3(a) based on different combinations of species and their relative abundance.

\section{Distribution in relation to physical-chemical conditions}

Five physical-chemical parameters were measured mostly once during spring months at 53 sampling sites in the Krka, Zrmanja and Una systems (more measurements, 2-11, taken at the main springs of these rivers were averaged) (Table 1). Correlation-based PCA with abundance of six gammarid taxa, four physical-chemical parameters (oxygen saturation was not included since it was strongly positively correlated with oxygen concentration), altitude and distance to the source showed that conductivity had the largest influence on grouping of these sites (47\% of total variation explained by the first two axes). Regarding the differences between sites in different basins for all five parameters and altitude, distance from the source and mean width (log-transformed values), significant results were found only for conductivity and altitude (ANOVA, $P<0.05$ ). A Fisher's least significant difference post-hoc test revealed that sites in the Zrmanja basin had significantly lower conductivity (avg-346 $\mu \mathrm{S} . \mathrm{cm}^{-1}$ ) than sites in the Krka (485 $\left.\mu \mathrm{S} . \mathrm{cm}^{-1}\right)$ and Una $\left(445 \mu \mathrm{S} . \mathrm{cm}^{-1}\right)$, while sites in the Una Basin were at significantly higher mean altitude (Una-335 m, Krka-215 m, Zrmanja-143 m). When grouped according to the three endemic gammarids present (Table 1), physical-chemical parameters had very similar mean values, but different ranges. $F$. dalmatinus dalmatinus, much more widespread in the Zrmanja and Una, has been found in a wider range of conditions than F. d. krkensis. E. acarinatus, distributed in the Krka as well as in the upper and middle Una, has been found in even higher ranges of temperature and conductivity values than $F$. $d$. dalmatinus. The range of the conductivity values in which E. acarinatus was found was also strikingly large (Table 1), but the highest conductivity, around $1000 \mu \mathrm{S} . \mathrm{cm}^{-1}$, was recorded only at two upstream sites in Butižnica (Krka right tributary). 
Table 2. Temperature conditions at six gauging stations $(\mathrm{G})$ and at Roški slap.

\begin{tabular}{|c|c|c|c|c|c|c|c|}
\hline River & Station name & $\begin{array}{l}\text { Alttitude, } \\
\text { (m a.s.l.) }\end{array}$ & $\begin{array}{c}\text { Distance } \\
\text { from main } \\
\text { source }(\mathrm{km})\end{array}$ & $\begin{array}{c}\text { Mean } \\
\text { annual } \\
\text { discharge } \\
\left(\mathrm{m}^{3 \cdot} \mathrm{s}^{-1}\right)\end{array}$ & $\begin{array}{c}\text { Water } \\
\text { temperature } \\
\text { data record } \\
\text { period }\end{array}$ & $\begin{array}{c}\text { Mean } \\
\text { annual water } \\
\text { temperature } \\
\left({ }^{\circ} \mathrm{C}\right)\end{array}$ & $\begin{array}{c}\text { Water } \\
\text { temperature }\left({ }^{\circ} \mathrm{C}\right) \\
(\min ) \text { avg mo min-avg } \\
\text { mo max (max) }\end{array}$ \\
\hline \multirow[t]{3}{*}{ Zrmanja } & Palanka (G1) & 255 & 10 & 5.2 & $1965-1990$ & 9,1 & $(1.0) 4.1-12.9(14.0)$ \\
\hline & Žegar (G2) & 50 & 41 & 9.8 & $1948-1990$ & 11,6 & (3.4) $5.8-15.8(18.8)$ \\
\hline & Jankovića buk ${ }^{\mathrm{a}}(\mathrm{G} 3)$ & 3 & 56 & 39.0 & $1953-1990$ & 12,6 & $7.9-19.0$ \\
\hline \multirow[t]{4}{*}{ Krka } & Knin $(G 4)$ & 230 & 4,6 & 23.3 & 1999-2009 & 10,4 & (6.0) 7.2-13.4 (15.2) \\
\hline & Roški slap ${ }^{b}$ & 51 & 38.5 & 47.6 & $2002-2003$ & 13,1 & $7.7-20.9$ \\
\hline & Skradinski buk-upper (G5) & 30 & 52.1 & 61.2 & $1975-2008$ & 15,4 & (3.5) 6.4-25.5 (27.0) \\
\hline & Skradinski buk-lower (G6) & 4 & 52.45 & 61.6 & 1959-1975 & 15,7 & (5.5) 9.7-24.1(25.5) \\
\hline
\end{tabular}

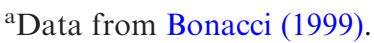

${ }^{b}$ where water temperatures were measured with a data logger over 1 year (every hour) (February 2002-January 2003). Temperature range: (absolute min.) average monthly minimum - average monthly maximum (absolute max.).

In order to provide some data on thermal tolerance of the studied gammarids, we considered their longitudinal distribution along the Krka and Zrmanja in relation to temperature. All the available daily temperature records from the five gauging stations (Fig. 1(b)), literature data (Bonacci, 1999) and our own data logger measurements at the site Krka-Roški Slap taken over a 1 year period every hour are shown in Table 2. The gauging station KrkaKnin (G4 in Fig. 2) is located about 4.5 km downstream of the main spring of the Krka and about $1.5 \mathrm{~km}$ downstream from the most downstream edge of $F$. dalmatinus krkenskis longitudinal distribution in the Krka. Further, temperature was measured in all four seasons $(n=11)$ at site $\mathrm{K} 1$ in Krka ( $\sim 200 \mathrm{~m}$ downstream from the main spring) and ranged from 9.7 to $10.7^{\circ} \mathrm{C}$ (mean $T w=10.3^{\circ} \mathrm{C}$ ). At the gauging station $\mathrm{G} 4$, the temperature range was $7.6-13.4^{\circ} \mathrm{C}$ with an average annual temperature of $10.4^{\circ} \mathrm{C}$, almost the same as in the previous case. Temperature conditions throughout the distribution area of $F$. dalmatinus dalmatinus had a much wider range. The lowest values were in the main spring of $\mathrm{Zrmanja}\left(8.7^{\circ} \mathrm{C}\right)$ and in the springs of Krupa and Dobarnica (ca. $10^{\circ} \mathrm{C}$ ). Generally, it ranged from 8.7 to $18.3{ }^{\circ} \mathrm{C}$. Temperatures at the gauging stations G1 and G2 (Table 2) were similar to those near the end of the upper Zrmanja and at the beginning of the lower Zrmanja in which F.d.d. was highly abundant. For the most downstream sites with F.d.d. $(0.9 \mathrm{~km}$ downstream from the Krupa confluence and at the Dobarnica confluence) the temperature conditions may only be interpolated since these sites are between the gauging stations $\mathrm{G} 2$ (with F.d.d.) and G3 (without F.d.d.). It can be inferred that the average annual temperatures at these sites are probably between 12 and $13{ }^{\circ} \mathrm{C}$, with the probable range of $6-18{ }^{\circ} \mathrm{C}$. E. acarinatus thrives in a much wider range of temperatures, from the relatively colder and more stable conditions in the upper courses of the Krka and Una to Roški Slap waterfall at Krka where the temperature ranged from 7.7 to $20.9^{\circ} \mathrm{C}$ (average $T w=13.1^{\circ} \mathrm{C}$ ) and Skradinski Buk (G5 and 6 in Fig. 2), a large travertine waterfall and the most downstream freshwater site of the Krka, with temperature amplitude of $23.5^{\circ} \mathrm{C}$ (Table 2). At Roški Slap, E.a. was abundant, while at Skradinski Buk it was a very rare species, which indicates that wider range and higher average annual temperatures at Skradinski Buk are probably beyond the range tolerated by this species.

The relative abundance of $F$. dalmatinus dalmatinus was significantly higher in springs than in all the other sites pooled together $(\mathrm{M}-\mathrm{W} U$-test, $P<0.01)$. On the other hand, the relative abundance of $F$. dalmatinus krkensis was higher $(\mathrm{M}-\mathrm{W}$ test, $P<0.05)$ at three sites in the Kosovčica system (Ko1, Ko2, Sp1) in comparison with five other sites where it also occurred.

\section{Microhabitat preference}

Density and relative abundance of gammarids was studied at three sites, Krka-upper course-K1, Zrmanja-Z6 and Dobarnica-spring-D1, in moss and on the stony substrate. At site K1, three species, F. dalmatinus krkensis, $E$. acarinatus and $G$. balcanicus, co-occurred. All the species reached 7-8 times higher density in moss microhabitats, and these differences were significant for $F$. dalmatinus krkensis and $G$. balcanicus ( $t$-test of log-transformed density, $P<0.05, \quad n=5$ ), while for E. acarinatus this difference was marginally not significant ( $t$-test, $P=0.06)$. Unidentified juvenile gammarids had 17 times higher density in moss $(t$-test, $P<0.05)$, while total gammarid density was also 14 times and significantly higher in moss $(t$-test, $P<0.05) . F$. dalmatinus krkensis had the highest density in both microhabitat types at K1 (Fig. 4(a)), but between-species differences in density were not significant in either case (ANOVA, $P>0.1$ ). Comparison of the relative abundance of all these species (Fig. 4(b)) revealed significantly higher $F$. dalmatinus krkensis relative abundance in the moss microhabitat (Kruskal-Wallis test, $P<0.01$ ), while the relative abundances of the other two species did not differ significantly. Also, there were no between-species differences in relative abundance on the stony substrate (Kruskal-Wallis test, $P>0.05)$. F . dalmatinus krkensis was generally the most abundant gammarid on the stony substrate; however, its prevalence was not statistically significant (KruskalWallis test, $P>0.05$ ). 



Fig. 4. (a) Density of Fontogammarus dalmatinus krkensis (F.d.k.) Echinogammarus acarinatus (E.a.) and Gammarus balcanicus $(G . b$.) in the upper course of the Krka River (K1) (* indicates a significant difference between microhabitats, $t$-test, $P<0.05$ ); (b) relative abundance of three species at site K1 (letters indicate results of post-hoc multiple comparisons by ranks, different letters indicate a significant difference, $P<0.05$ ).

Comparison of density and relative abundance of F. dalmatinus dalmatinus (F.d.d.) and G. balcanicus (G.b.) at sites D1 (Figs. 5(a) and (b)) and Z6 (Fig. 5(c) and (d)) revealed a similar pattern, with $F . d . d$. dominance in moss microhabitats in terms of density and relative abundance. At site D1, such differences between microhabitats could not be tested, since only one sample was collected at this site from the stony substrate. Juveniles and total gammarid densities at D1 and Z6 were again 5-6 times higher in moss microhabitats $(t$-test, $P<0.05)$. In mosses at site D1, F.d.d. reached both higher density $(t$-test, $P<0.01)$ and relative abundance $(\mathrm{M}-\mathrm{W} U$-test, $P<0.01)$ than G.b., and F.d.d. was more abundant in both microhabitats (Figs. 5(a) and (b)). At site Z6, F.d.d. had higher density $(t$-test, $P<0.05)$ and relative abundance $(\mathrm{M}-\mathrm{W} U$-test, $P<0.001$ ) in moss microhabitats (Fig. 5(c) and (d)), while densities of G.b. and F.d.d. did not differ ( $t$-test, $P>0.05$ ), and relative abundance of G.b. on stony substrate was significantly higher (M-W $U$-test, $P<0.01)$.

\section{Conservation status}

All three studied gammarid taxa were assessed using IUCN Red List Categories and Criteria (Version 3.1) (IUCN, 2012) and guidelines (IUCN Standards and Petitions Subcommittee, 2014). Due to lack of long-term population data, only criterion B "Geographic range size, and fragmentation, decline or fluctuations" could be applied in their cases. E. acarinatus was listed as a species of Least Concern (LC), because it is widespread and abundant, not likely to qualify it for one of the threatened categories in the near future.

Both subspecies $F$. dalmatinus dalmatinus and F. dalmatinus krkensis are listed as Near Threatened (NT) because they are likely to qualify for one of the threatened categories (Vulnerable or Endangered) in the near future. The threatened category could not be applied for these taxa because only one of at least two subcriteria of B2 was fulfilled. The first subspecies (F.d.d.) meets area requirements under criterion $\mathrm{B}$ for the Endangered category $\left(\mathrm{EOO}<5000 \mathrm{~km}^{2}\right.$ and $\left.\mathrm{AOO}<500 \mathrm{~km}^{2}\right)$ as it occurs in nine locations (subcriteria for Vulnerable category), it is not severely fragmented, there is not enough evidence for continuing decline and there are no extreme fluctuations in its population size. According to the IUCN definition (IUCN, 2012), location is a geographically or ecologically distinct area in which a single threatening event (pollution in our case) can rapidly affect all individuals of the taxon present. The second subspecies (F.d.k.) meets area requirements under criterion B for the Endangered category. Both subspecies would qualify for the Vulnerable (F.d.d.) or Endangered (F.d.k.) category if a continuing decline in the quality of its habitats and number of its subpopulations could be supported by strong arguments (see Discussion).

\section{Discussion}

\section{Distribution}

The high level of endemism of Balkan freshwater fauna is well known; however, not much is known about the distribution and ecology of the local species (for reviews see Bănărescu, 2004; Blondel et al., 2010; Tierno de Figueroa et al., 2013). Particularly, rivers of the Dinaric karst suffer from a chronic lack of biogeographic and ecological studies, even in the case of fish, generally attracting more attention from scientists (Kottelat and Freyhof, 2007; Oikonomou et al., 2014). By comparison, aquatic invertebrates remain practically unstudied. Importantly, distributional and ecological data are essential to rationalize conservation strategies for species and their habitats. Also, they may provide insight into complex historical processes underlying intricate and often mysterious distribution patterns observed among many Balkan freshwater species. The ecology of endemic species should be of general interest as it may provide a basis to understand their limited distributions and mechanisms behind their coexistence with more widespread and euryoecious species (e.g., Žganec et al., 2011, 2013). The distribution and ecology of the two endemic species of gammarids, $E$. acarinatus and $F$. dalmatinus in the Dinaric karst rivers represent an interesting case study within such a framework, that may also contribute to better understanding distribution patterns of other Balkan freshwater endemics. 
a



c

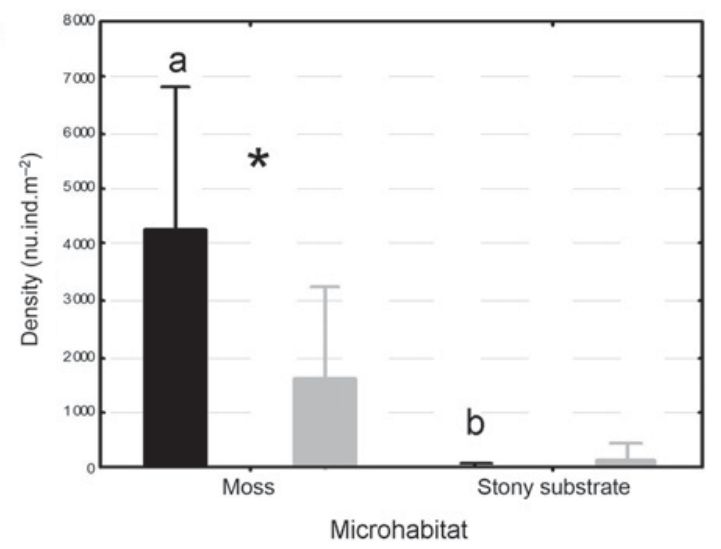

b


Fig. 5. (a) Density and (b) relative abundance of Fontogammarus dalmatinus dalmatinus and Gammarus balcanicus in the Dobarnica spring-D1 (asterisks indicate a significant difference between species in the moss microhabitat, $t$-test, $P<0.05, n$-number of samples); (c) density and (d) relative abundance of species Fontogammarus dalmatinus dalmatinus and Gammarus balcanicus at site Zrmanja-Z6 (the asterisk indicates a significant difference between species in each microhabitat, while different letters indicate significant differences between microhabitats for each species separately, $P<0.05)$.

E. acarinatus was shown to have rather wide distribution, from the Una River in the northwest to the lower course and delta of the Neretva River in southeast. In the rivers of the AS drainage area, this species has a very peculiar distribution, as it is present only in the Krka and Neretva Basins, and absent from the Zrmanja, Cetina and Jadro Rivers (Fig. 1). We consider the literature record of $E$. acarinatus in the Jadro (Karaman, 1970) questionable since we did not confirm it during the present study. Also, its identification in a tributary of Vransko Lake by the same author could not be confirmed since we did not find the species in the lake nor in its tributaries. However, we found a very similar species, Echinogammarus stocki, in Vransko Lake (Žganec, unpublished). Karaman (1970) separated E. stocki from E. acarinatus by slight morphological differences, but also by ecology. The former species lives in brackish waters, while the latter lives in freshwater. Thus, all the questionable literature records in the brackish waters of the Vransko Lake and of the Jadro River should probably be attributed to E. stocki. Absence of $E$. acarinatus from the Neretva River delta, where it was reported by Gottstein et al. (2008), could be a consequence of pollution and/or the increasing salinity level in the delta over the last decade. Furthermore, populations of E. acarinatus from the BS basin show some morphological differences (Karaman, 1931a, 1931b; Pljakić, 1962; Karaman, 1970) from those living in the AS basin. Molecular studies are needed to fully clarify their taxonomic status. Concluding from all the available data, we assume continuous distribution of $E$. acarinatus in the upper and middle reaches of the Una, Vrbas and Bosna Rivers. Close proximity of the upper Una and Butižnica (Krka tributary), and upper Vrbas and Bosna tributaries to the Neretva right tributaries, indicate that river capture events could explain the presence of E. acarinatus in the Krka and Neretva Basins. River capture events probably happened during the Pliocene period when Dalmatian plateau uplift and active incision of rivers occurred (Mantovani et al. 1993). Another amphipod that occurs in both the BS (Una) and AS (Zrmanja and Krka) basins is G. balcanicus. The same type of distribution in the Una, Zrmanja and Krka is also shared by the crayfish Austropotamobius torrentium (Maguire et al., 2011) and fish Cottus gobio (Jelić, 2012). Such trans-watershed ranges support the assumption of past epigean connections between the paleoriver systems of West Bosnia and Herzegovina (Una and Vrbas River systems) and the paleorivers of Dalmatia (Krka and Zrmanja River systems) (De Leeuw et al., 2012; Vlahović et al., 2012). 
The Croatian endemic $F$. dalmatinus, was described from the spring of the Krka River (Karaman, 1931a). Its distribution in the Zrmanja, Krka and Una is intriguing. Based on faunistic data and preliminary molecular analyses (Mamos et al., 2013), we assume that it originated in the Miocene Lake System of the North Dalmatian Plateau. Further molecular study will try to reconstruct subsequent complex geological processes that resulted in the present distribution of $F$. dalmatinus populations in the Zrmanja, Krka and Una. The distribution of this species also testifies the past connection between the upper Zrmanja and Krka. Precise dating of the river separation event is not possible since there are no data on absolute age of the alluvial sediments preserved in the dry valley which once connected Zrmanja and Krka and is still visible in present relief (dashed line in Fig. 2). Fritz (1972) assumes that Krka-Zrmanja separation happened during the upper Pleistocene, approx. 40000 years before the present, but this age most probably overestimates the later incision rates of the canyons. Therefore, the separation event should not be precisely dated due to the lack of data, but rather roughly estimated as Middle to Upper Pleistocene, i.e., during the last $1 \mathrm{Ma}$. After the Krka and Zrmanja separated, $F$. dalmatinus krkensis and $F$. d. dalmatinus started to diverge on the morphological level (Karaman, 1965). The present subterranean karstic flow from the upper Zrmanja to the Miljacka spring at the right bank of the Krka canyon connects these two rivers (Bonacci, 1999). It seems that the subspecies is not able to disperse from the Zrmanja to the Krka by this subterranean connection, since we did not find F. dalmatinus dalmatinus in the Miljacka spring.

\section{Ecological notes on studied taxa}

E. acarinatus is a eurivalent species that tolerates a wide range of environmental conditions. Its distribution extends from springs (main spring of the Krka and four smaller springs) to the lower course of the Krka (travertine cascades and waterfalls Roški Slap and Skradinski Buk) and it was even found in the Visovac Lake, although with very low abundance. Finding the species in the middle course of the Una downstream of Bihać, where higher levels of pollution were observed (personal observation), also indicates that it is probably resistant to poor water quality. Therefore, it can be assumed that it is a much more widespread species in the upper and middle parts of the Una, Vrbas, Bosna and Neretva Rivers.

F. dalmatinus krkensis is crenophilous with the narrowest ecological valence for almost all the measured parameters (Table 1). Its relative abundance at three sites in the Kosovčica Basin, where it co-occurs only with G. balcanicus, is significantly higher than at the other six sites where it was found. In the most upstream site in Krka (K1, $\sim 200 \mathrm{~m}$ downstream main spring), $F$. dalmatinus krkensis had the highest density and relative abundance of the three gammarids present (Fig. (4)), and at three sites in Kosovčica, its relative abundance was higher than that of G. balcanicus. This could possibly be attributed to better adaptation of $F$. dalmatinus krkensis to stable thermal conditions in the upper Krka and Kosovčica. At the five other sites where E. acarinatus was more abundant, the relative abundance of $F$. dalmatinus krkensis was low (1-20\%). These results could be a consequence of interference competition of these two species of similar size, leading to higher abundance of more successful species in certain conditions. Interference competition is often assumed to be responsible for the replacement of one gammarid species by another (e.g., Piscart et al., 2007; van Riel et al., 2007). However, during the collection of qualitative samples at eight other sites, we did not discriminate different types of microhabitats, and since it was shown that moss and stone microhabitats have different relative abundances, this could simply be a consequence of varying sampling methodology.

$F$. dalmatinus dalmatinus is more widespread. It inhabits the middle parts of the Zrmanja and Una and tolerates a wider range of environmental conditions, such as temperature and conductivity, than $F . d$. krkensis (Table 1). Since its relative abundance is higher in springs than at other sites, we can conclude that, generally, this species finds optimal conditions in relatively colder and more stable springs and upper river courses. However, it is also able to thrive in more variable abiotic, especially thermal, conditions. Therefore, it seems that tolerance for a higher range of abiotic conditions enables wider distribution of $F$. d. dalmatinus. Such ecological differences and also differences in fecundity observed by Đurić (2009) indicate that the taxonomic status of the two Fontogammarus subspecies should be verified.

\section{Microhabitat preference}

Aquatic mosses, which are widespread in freshwater ecosystems (Baattrup-Pedersen et al., 2006), can provide important refuges for stream invertebrates, e.g., from strong currents (Gregg and Rose, 1982; Suren, 1991) and vertebrate predators (Parker et al., 2007). In the upper courses of the Croatian karst rivers, mosses cover considerable surfaces of substratum, often being the most dominant microhabitat type (Pavletić and Matoničkin, 1965). Mosses also represent an important building element of travertine waterfalls, making the Dinaric karst rivers a world-scale phenomenon. Such waterfalls may be found along large parts of the courses of the Krka, Una, Zrmanja and Krupa. In the case of all gammarid species and particularly in the case of the smaller endemics such as $E$. cari, E. acarinatus and $F$. dalmatinus, mosses are the most densely populated microhabitat (Žganec et al., 2013; this study). Such a microhabitat is perfect for smaller species as it provides protection from current and predators, and also it is an abundant supply of food. For example, Suren (1991) showed that mosses act as very efficient traps for small particles of detritus. Interestingly, unlike previous studies (Žganec and Gottstein, 2009; Žganec et al., 2013) which recorded dominance of larger 
gammarid species on stony substrates and smaller ones in mosses, we observed dominance of smaller species of gammarids in both microhabitat types, stones and mosses, at the upper course of the Krka (K1) and in the Dobarnica spring (D1). The situation in the upper course of the Krka is especially interesting as all three gammarids are found there together, with smaller species, $F$. dalmatinus krkensis and $E$. acarinatus being more abundant than the larger $G$. balcanicus in both microhabitat types. We assume that this may simply be a consequence of the fact that smaller species can reach higher abundance since their energy requirements are lower (White et al., 2007), especially in habitats with limited amounts of food. Site K1 could be assumed to be food limited due to the lack of packs of detritus/leaves - likely a result of a very strong water current and absence of detritus in upstream sections of the river. Further, since mosses are often much more densely packed than other macrophytes, especially in strong currents (Suren, 1991), the smaller species of gammarids may be much more abundant in such microhabitats. However, it should be pointed out that between-species differences observed in this study were based only on larger/adult specimens of gammarids and different results could be obtained for juvenile specimens if they could be identified to species level. The density of juvenile gammarids as well as the total density of gammarids (adults + juveniles) was significantly higher than on the stony substrate at all three sites. In general, at all the three sites where we studied gammarid microdistribution, as well as in a previous study (Žganec et al., 2013), smaller gammarid species dominated in terms of density and relative abundance in moss microhabitats. Usually, in cases of two coexisting gammarid species, we observed dominance of smaller gammarid species in mosses and larger ones on stony substrates (Žganec and Gottstein, 2009; Žganec et al., 2013; this study). However, as we also showed in this study, an exception to this "rule" could be expected in springs and in a few hundred meters of course of large karstic rivers where mosses dominate and/or food is limited.

\section{Species conservation status}

Most freshwater gammarids included in the Global IUCN Red List are subterranean North American species (IUCN Red List, 2015). So far, most of the endemic epigean freshwater species of gammarids have not been assessed. With this work and previous studies (Gottstein et al., 2011; Žganec et al., 2013) the conservation status for all Croatian endemic gammarid taxa may be updated and completed. The need for such categorization is particularly striking in the case of $E$. cari that lost more than $50 \%$ of its distribution area and became Endangered (EN) in 2010 due to damming activity (Žganec et al., 2013).

F. dalmatinus krkensis is listed as NT as it would qualify for the EN category if there were any data that would enable estimation, projection or inference of continuing population decline. However, with the existing data we can only suspect continuing decline in the quality of the species habitat and number of its locations, but this is not allowed for criterion B2 according to IUCN guidelines (IUCN Standards and Petitions Subcommittee, 2014). The estimated distribution of this species encompasses only ca. $5 \mathrm{~km}$ of stream/river length, i.e., an area of about $0.1 \mathrm{~km}^{2}$. Despite such a small area, and the fact that six isolated populations could be identified (one in the upper course of the Krka, the other in the upper Kosovčica and four in the small springs of the Krka and Kosovčica tributaries), it could not be considered to be severely fragmented. Since it is restricted to springs and upper river courses with relatively cold and stable thermal conditions, we suspect that its distribution has been and will be declining due to increasing temperatures resulting from global warming. Analyses of long-term trends in water temperature over the last 50 years have revealed significant increases in average annual temperatures at three karst rivers in Central Croatia, by $0.17,0.44$ and $0.48^{\circ} \mathrm{C}$ per decade (Žganec, 2012). Further, three of five springs where it occurs have been captured and used for water supply, but their reduced flows are still sufficient for survival of the subspecies. Also, pollution from gypsum mine wastewater has probably caused reduction of the $F$. dalmatinus krkensis distribution range in the Kosovčica stream. The widespread and eurivalent $G$. balcanicus was found to have degraded exoskeletons downstream from the confluence of the river's small left tributary Jaruga which brings wastewater with high concentrations of sulfates and heavy-metals from the nearby gypsum mine (Ternjej et al., 2014). This pollution probably restricted distribution of $F$. dalmatinus krkensis to the first $800 \mathrm{~m}$ of the Kosovčica. It is also possible that the wastewater from the local trout fish pond discharged to the Krka along with hydromorphological alterations of its upper course are responsible for low abundance of $F$. dalmatinus krkensis in this part of the river. Two populations occur within the Natura 2000 area (Krčić), but the target species of this site are terrestrial species (Duplić et al., 2012). The four other populations (in Kosovčica and four other springs) are located outside the protected areas. They are threatened by plans to increase water abstraction, plans to build small hydropower plants and by accidental pollution from local settlements. Thus, the conservation measures for this species should focus on careful planning of further water abstraction, pollution control and also strict protection of the upper Krka against hydromorphological alterations. If further studies on the subspecies, planned by the authors, reveal further reduction of its distribution and abundance, its status could change to Endangered. Conservation actions could, for example, include the simple measures of facilitating enlargement of areas covered by moss in the upper Krka and Kosovčica rivers.

$F$. dalmatinus dalmatinus is more widespread and occurs along ca. $47 \mathrm{~km}$ of the total length of the Zrmanja and its tributaries, and along about $6 \mathrm{~km}$ in the upper course of the Una. Its estimated distribution area is, however, only about $1.4 \mathrm{~km}^{2}$. It meets area requirements under criterion $\mathrm{B}$ for the Endangered category 
$\left(\mathrm{EOO}<5000 \mathrm{~km}^{2}\right.$ and $\left.\mathrm{AOO}<500 \mathrm{~km}^{2}\right)$ and Vulnerable category since its estimated number of locations is 9 . However, it is listed as NT because continuing decline could not be estimated, projected, or inferred due to lack of data. Global warming has probably already caused reduction of its distribution area and this trend could also be expected in the future. Future studies on the subspecies should focus on the assumed decline of its distribution area. This subspecies is relatively well protected since the whole Zrmanja and upper Una are Natura 2000 sites, while the Zrmanja and Krupa are also located within the Velebit Natural Park.

The conservation status of $E$. acarinatus is LC, although it meets the area requirements under criterion B2 for threatened categories. This species is probably widespread and abundant in the dense network of watercourses of the upper Una, Vrbas, Bosna and Neretva Basins, similar to the situation in the Krka Basin. However, there is an indication that its distribution area is shrinking since its presence in the delta of the Neretva River, previously reported by Gottstein et al. (2008) could not be confirmed. If the species has really disappeared from the delta, this could be the consequence of water pollution and/or increasing salinity due to reduction of flow caused by upstream hydropower plants and climate change. The populations of E. acarinatus in the Krka and Una are relatively well protected since most of the river sections they inhabit are located in the national parks of Krka (Croatia) and Una (Bosnia and Herzegovina). Further, a water treatment plant which is being constructed for the town of Knin will eliminate water pollution - the greatest threat for this species in the Krka.

Together with $E$. thoni in the NT category (Gottstein et al., 2011), there are altogether five Croatian endemic gammarid taxa (one spp. and two sspp.) with an assessed conservation status: one Endangered species (E. cari), three NT (E. thoni, F. d. dalmatinus and F.d. krkensis) and one LC (E. acarinatus).

Information on species ecology and population trends is, in general, poor in the case of most freshwater taxa, even including economically important groups such as fishes. Without such information, it is difficult to assess the consequence of pressures or the risk of extinction for particular species (Revenga et al., 2005). Our study illustrates the importance of detailed distribution data combined with information on the ecology of local populations and taxonomic expertise for reliable assessment of conservation status in the case of endemic freshwater species. Conservation measures that would ensure longterm survival of the studied gammarids should focus on management activities aimed at restricting further destruction and pollution of the watercourses and springs they inhabit.

Acknowledgements. We acknowledge the assistance of Sanja Gottstein, Nina Jeran, Ana Slavikovski, Petra Peleš, Ivana Pušić, Dijana Beneta, Matea Baburić, Mateja Gazić, Meri Barišić and Jelena Tojčić during the field work.

\section{References}

Baattrup-Pedersen A., Szoszkiewicz K., Nijboer R., O’Hare M. and Ferreira T., 2006. Macrophyte communities in unimpacted European streams: variability in assemblage patterns, abundance and diversity. Hydrobiologia, 566, 179-196.

Bănărescu P.M. (ed.), 2004. Distribution Pattern of the Aquatic Fauna of the Balkan Peninsula, Kulwer Academic Publishers, Dordrecht, 357 p.

Blondel J., Aronson J., Bodiou J.-Y. and Boeuf G., 2010. The Mediterranean Region: biological diversity through time and space, Oxford University Press, Oxford, 376 p.

Bonacci O., 1999. Water circulation in karst and determination of catchment areas: example of the River Zrmanja. Hydrol. Sci. J., 44, 373-385.

Borrell B., 2012. One-fifth of invertebrate species at risk of extinction. Nat. News, 489, 324-325.

De Leeuw A., Mandić O., Krijgsman W., Kuiper K. and Hrvatović H., 2012. Paleomagnetic and geochronologic constraints on the geodynamic evolution of the Central Dinarides. Tectonophysics, 530-531, 286-298.

Dudgeon D., Arthington A.H., Gessner M.O., Kawabata Z.-I., Knowler D.J., Lévêque C., Naiman R.J., Prieur-Richard A.-H., Soto D., Stiassny M.L.J. and Sullivan C.A., 2006. Freshwater biodiversity: importance, threats, status and conservation challenges. Biol. Rev., 81, 163-182.

Duplić A., Plavac I., Radović J., Rodić P. and Topić R., 2012. Proposal of Ecological Network Natura 2000, State Institute for Nature Protection, Zagreb, 460 p. (in Croatian).

Đuric P., 2009. Distribution and ecology of endemic species Fontogammarus dalmatinus S. Karaman (Amphipoda, Gammaridae) in Zrmanja and Krka River Basins. Master thesis, University of Zagreb, Croatia, 109 p.

European Commission 2011. Our Life Insurance, Our Natural Capital: An EU Biodiversity Strategy to 2020, European Commission, Brussels, 20 p.

Fritz F., 1972. Razvitak gornjeg toka rijeke Zrmanje (in Croatian). Car. Iugosl., 8, 1-16.

Gottstein S., Žganec K., Kipson S. and Stančić Z., 2008. Amphipods as indicators of environmental changes in the delta of the Neretva river, Croatia, 3rd International Symposium of ecologists of Montenegro, Herceg-Novi. 421-431.

Gottstein S., Hudina S., Lucić A., Maguire I., Ternjej I. and Žganec K., 2011. Red List of Freshwater and Brackishwater Crustaceans of Croatia (in Croatian), State Institute for Nature Protection, Zagreb, 47 p.

Grabowski M., Bacela-Spychalska K. and Pešić V., 2014. Reproductive traits and conservation needs of the endemic gammarid Laurogammarus scutarensis (Schäferna, 1922) from the Skadar Lakesystem, Balkan Peninsula. Limnologica, 47, 44-51.

Gregg W.W. and Rose F.L., 1982. The effects of aquatic macrophytes on the stream microenvironment. Aquat. Bot., 14, 309-324.

Griffiths H.I., Kryštufek B. and Reed J.M. (eds.), 2004. Balkan Biodiversity. Pattern and Process in the European Hotspot, Kulwer Academic Publishers, Dordrecht, 357 p.

IUCN 2012. IUCN Red List Categories and Criteria. Version 3.1, Second edition, IUCN, Gland, 32 p. 
IUCN Red List, 2015. Amphipoda. Accessed online 23 June 2015, http://www.iucnredlist.org/search.

IUCN Standards and Petitions Subcommittee, 2014. Guidelines for Using the IUCN Red List Categories and Criteria. Version 11, available online at: http://intranet.iucn.org/ webfiles/doc/SSC/RedList/RedListGuidelines.pdf

Jelić D., 2012. New data on the distribution of Cottus gobio (Scorpeniformes; Cottidae) in Croatia with special overview of the Adriatic Basin. Ribarstvo, 70, 1-8.

Karaman G.S., 1965. Über die Gattung Fontogammarus S. Karaman in Jugoslawien. Fragm. Balc., 13, 81-89.

Karaman G.S., 1970. 25. prilog poznavanju Amphipoda. Kritička zapažanja o vrstama Echinogammarus acarinatus (S. Kar. 1931) i Echinogammarus stocki n. sp. Poljoprivreda $i$ šumarstvo, 16, 45-66.

Karaman S.L., 1931a. III. Beitrag zur Kenntnis der Amphipoden Jugoslaviens, sowie einiger Arten aus Griechenland. Prirodoslovne Razprave, 1, 31-66.

Karaman S.L., 1931b. 4. Beitrag zur Kenntnis der Amphipoden. Bull. Soc. Sci. Skoplje, 9, 93-107.

Karaman S.L., 1934. VI Betraig zur Kenntnis jugoslawischer Süßwasseramphipoden. Zool. Anz., 11, 325-333.

Karaman S.L., 1935. VII Betraig zur Kenntnis der Süßwasseramphipoden. Zool. Anz., 5, 125-130.

Karaman S.L., 1953. Pontokaspische Amphipoden der jugoslavischen. Fauna Acta Mus. Mac. Sci. Nat., 1, 21-60.

Karaman G.S. and Pinkster S., 1977a. Freshwater Gammarus species from Europe, North Africa and adjacent regions of Asia (Crustacea - Amphipoda) Part I. Gammarus pulex group and related species. Bijdr. Dierkd., 47, 1-97.

Karaman G.S. and Pinkster S., 1977b. Freshwater Gammarus species from Europe, North Africa and adjacent regions of Asia (Crustacea - Amphipoda) Part II. Gammarus roeseligroup and related species. Bijdr. Dierkd., 47, 165-196.

Karaman G.S. and Pinkster S., 1987. Freshwater Gammarus species from Europe, North Africa and adjecent regions of Asia (Crustacea-Amphipoda). Part III. Gammarus balcanicus - group and related species. Bijdr. Dierkd., 57, 207-260.

Kottelat M. and Freyhof J., 2007. Handbook of European Freshwater Fishes, Kottelat, Cornol and Freyhof, Berlin, $646 \mathrm{p}$.

Maguire I., Jelić M. and Klobučar G., 2011. Update on the distribution of freshwater crayfish in Croatia. Knowl. Manag. Aquat. Ecosyst., 401, 1-10.

Mantovani E., Albarelo D., Babbucci D. and Tamburelli C., 1993. Post-Tortonian deformation pattern in the central Mediterranean: a result of extrusion tectonics driven by the Africa-Eurasia convergence. In: Boschi E., Mantovani E. and Morelli A. (eds.), Recent Evolution and Seismicity of the Mediterranean Region, NATO ASI Series, Dordrecht, The Netherlands, Kluwer Academic Publishers, 65-104.

Mamos T., Đurić P., Žganec K. and Grabowski M., 2013. Distribution and molecular diversity of Fontogammarus dalmatinus S. Karaman, 1931 endemic to the Dinaric karst. In: Grabowski M., Rachalewski M., and Konopacka A. (eds.), 15th International Colloqium on Amphipoda. Szczawnica, Poland, Piktor S.C. Lodz, 119.

Mamos T., Wattier R., Majda A., Sket B. and Grabowski M., 2014. Morphological vs. molecular delineation of taxa across montane regions in Europe: the case study of Gammarus balcanicus Schäferna, 1922 (Crustacea: Amphipoda). J. Zool. Syst. Evol. Res., 52, 237-248.
Mamos T., Wattier R., Burzynski A. and Grabowski M., 2015. The legacy of a vanished sea: a high level of diversification within a European freshwater amphipod species complex driven by 15 My of Paratethys regression. Mol. Ecol., http:// dx.doi.org/110.1111/mec.13499.

Oikonomou A., Leprieur F. and Leonardos I.D., 2014. Biogeography of freshwater fishes of the Balkan Peninsula. Hydrobiologia, 738, 205-220.

Parker J.D., Burkepile D.E., Collins D.O., Kubanek J. and Hay M.E., 2007. Stream mosses as chemically-defended refugia for freshwater macroinvertebrates. Oikos, 116, 302-312.

Pavletić Z. and Matoničkin I., 1965. Biological classification of upper reaches of karstic rivers (in Croatian). Acta Bot. Croat., 24, 151-162.

Pinkster S., 1993. A revision of the genus Echinogammarus Stebbing, 1899 with some notes on related genera (Crustacea, Amphipoda). Mem. Mus. Stor. Nat., 10, 1-185.

Piscart C., Manach A., Copp G.H. and Marmonier P., 2007. Distribution and microhabitats of native and non-native gammarids (Amphipoda, Crustacea) in Brittany, with particular reference to the endangered endemic sub-species Gammarus duebeni celticus. J. Biogeogr., 54, 524-533.

Pljakić M., 1962. Ein beitrag zur kenntins der Taxonomie, Vertailung und Migration des Gammarus pungens M. Edw. Izdanija, Zavod Ribar. Maked., Skopje, 3, 15-26.

Revenga C., Campbell I., Abell R., de Villiers P. and Bryer M., 2005. Prospects for monitoring freshwater ecosystems towards the 2010 targets. Philos. Trans. R. Soc. Lond. B, $360,397-413$.

Schäferna K., 1920. A contribution to the knowlege of Gammarida of the Adriatic region and their geographical distribution. Bull. Int. Acad. Sci. Bohème, 1920, 1-5.

Schäferna K., 1922. Amphipoda Balcanica (in Bohemian, English summary) Mém. Soc. R. Sci. Bohème, Prague for 1921-1922, 12, 1-111.

Strayer D.L., 2001. Endagered freshwater invertebrates. In: Levin S. (ed.), Encyclopedia of Biodiversity, Academic Press, San Diego, 425-439 p.

Strayer D.L., 2006. Challenges for freshwater invertebrate conservation. J. N. Am. Benthol. Soc., 25, 271-287.

Suren A.M., 1991. Bryophytes as invertebrate habitat in two New Zealand alpine streams. Freshw. Biol., 26, 399-418.

Ternjej I., Mihaljević Z., Ivković M., Previšić A., Stanković I., Maldini K., Želježić D. and Kopjar N., 2014. The impact of gypsum mine water: a case study on morphology and DNA integrity in the freshwater invertebrate, Gammarus balcanicus. Environ. Pollut., 189, 229-238.

Tierno de Figueroa J.M., Lóppez-Rodríguez M.J., Fenoglio S., Sánchez-Castillo P. and Fochetti R., 2013. Freshwater biodiversity in the rivers of the Mediterranean Basin. Hydrobiologia, 719, 37-186.

Väinölä R., Witt J.D.S., Grabowski M., Bradbury J.H., Jażdżewski K. and Sket B., 2008. Global diversity of amphipods (Amphipoda; Crustacea) in freshwater. Hydrobiologia, 595, 241-255.

van Riel M.C., Healy E.P., van der Velde G. and bij de Vaate A., 2007. Interference competition among native and invader amphipods. Acta Oecol., 31, 282-289.

Vlahović I., Mandić O., Mrinjek E., Bergant S., Čosović V., de Leeuw A., Enos P., Hrvatović H., Matičec D., Mikša G., Nemec W., Pavelić D., Pencinger V., Velić I. and Vranjković A., 2012. Marine to continental depositional systems 
of Outer Dinarides foreland and intra-montane basins (Eocene-Miocene, Croatia and Bosnia-Herzegovina). J. Alp. Geol., 55, 401-466.

Weiss M., Macher J., Seefeldt M. and Leese F., 2014. Molecular evidence for further overlooked species within the Gammarus fossarum complex (Crustacea: Amphipoda). Hydrobiologia, 721, 165-184.

White E.P., Morgan Ernest S.K., Kerkhoff A.J. and Enquist B.J., 2007. Relationships between body size and abundance in ecology. Trends Ecol. Evol., 22, 323-330.

Woodward J. (ed.), 2009. The Physical Geography of the Mediterranean. Oxford University Press, Oxford, 704 p.

Zar J.H., 1996. Biostatistical Analysis, Prentice-Hall International, Inc., London, 662 p.

Žganec K., 2009. Distribution and Ecology of Epigean Fresh and Brakish Water Shrimps (Amphipoda: Gammaroidea) in Croatia, University of Zagreb, Zagreb, 214 p.

Žganec K., 2012. The effects of water diversion and climate change on hydrological alteration and temperature regime of karst rivers in central Croatia. Environ. Monit. Assess., 184, $5705-5723$.
Žganec K. and Gottstein S., 2009. The river before damming: distribution and ecological notes on the endemic species Echinogammarus cari (Amphipoda: Gammaridae) in the Dobra River and its tributaries, Croatia. Aquat. Ecol., 43, 105-115.

Žganec K., Gottstein S. and Đurić P., 2010a. Distribution of native and alien gammarids (Crustacea: Amphipoda) along the course of the Una River. Nat. Croat., 19, $141-150$.

Žganec K., Gottstein S., Grabowski M. and Platvoet D., 2010b. Distribution of the endemic amphipod species Echinogammarus thoni (Schäferna, 1922) in watercourses of the Balkan Peninsula. Lauterbornia, 69, 41-50.

Žganec K., Đuric P. and Gottstein S., 2011. Life history traits of the endangered endemic amphipod Echinogammarus cari (Crustacea, Gammaridae) from the Dinaric karst. Int. Rev. Hydrobiol., 96, 686-708.

Žganec K., Đurić P., Hudina S. and Gottstein S., 2013. Population and distribution changes of two coexisting river amphipods after the closure of a new large dam. Limnologica, 43, 460-468. 